\title{
Continuity and hybridity in language revival: The case of Manx
}

\author{
CHR I S T O P H E R L W I N (D) \\ Aberystwyth University, Wales
}

\section{A B S T R A C T}

This article presents a typology of phonological, morphosyntactic, and lexical features illustrative of factors conditioning the usage of speakers and writers of Revived Manx, including substratal influence from English; language ideologies prevalent within the revival movement, especially forms of linguistic purism; and language-specific features of Manx and its orthography. Evidence is taken primarily from a corpus of Revived Manx speech and writing. The observed features of Revived Manx are situated within Zuckermann's (2009, 2020) framework of 'hybridization' and 'revival linguistics', which takes Israeli Hebrew as the prototypical model of revernacularization of a non-L1 language. However, Manx arguably provides a more typical example of what to expect when a revived minority language remains predominantly an L2 for an indefinite period, with each new cohort of speakers able to reshape the target variety in the absence of a firmly established L1 norm. (Manx, Celtic, language revival, language ideology, language shift, language contact)*

\section{N T R O D U C T I O N}

This article presents a brief description and analysis of some of the categories of linguistic features found in contemporary Manx, by which present-day usage may diverge from the norms of the traditional language. Manx today is a revived Celtic language with no traditional native speakers. According to Zuckermann (2009, 2020) and Zuckerman \& Walsh (2011), languages revived initially as an L2, such as Israeli Hebrew, inevitably have a permanent 'hybrid' character, blending the substrate of the L1 of the 'founder generation' of revivalists with forms and patterns incompletely assimilated from the target language-even if they then become a fully vernacularized mother tongue of subsequent generations. We may compare the observation of Hinton \& Ahlers (1999:61) with regard to indigenous Californian languages now moribund as L1s:

In the situation of language revitalization in small speech communities, the new learners will one day be the sole bearers of the language, and therefore all of the patterns of simplification, interference, and incomplete learning that remain extant in the learners' speech will be a permanent part of that language. (Hinton \& Ahlers 1999:61)

(C) The Author(s), 2021. Published by Cambridge University Press. This is an Open Access article, distributed under the terms of the Creative Commons Attribution licence (http://creativecommons. org/licenses/by/4.0/), which permits unrestricted re-use, distribution, and reproduction in any medium, provided the original work is properly cited. 0047-4045/21 $\$ 15.00$ 
Such blending of the features of the target language with new patterns introduced through the process of L2 language revival can clearly be seen in the case of Revived Manx. The present case study also illustrates how the particular historically contingent idiosyncrasies of a given pair of linguistic systems and traditions can have a significant impact - for example, the complexities of the Manx orthography and how these are interpreted in relation to English. Language ideology is also shown to be an important variable, although a significant degree of commonality between language revitalization scenarios can be observed, as discussed below.

Zuckermann's (2009, 2020) work stresses the centrality of Hebrew (or 'Israeli') as the natural focus and prototype for his proposed field and paradigm of 'revival linguistics' or 'revivalistics', given that it is undoubtedly the most successful and best documented revival in terms of achieving large numbers of speakers and full sociolinguistic vitality as a community and subsequently state language (Blanc 1957; Nahir 1998). It may be argued, however, that revived minority languages such as Manx are in fact more typical, and in some ways more instructive, cases of language revival. Unlike Hebrew, but like most, perhaps all, other revived languages, Manx remains largely an L2, moulded by conscious learning by relatively small numbers of adults in each generation, rather than being subject to the usual unconscious processes of language change during intergenerational transmission of natively spoken languages. Even in the rare cases of L1 acquisition, English is likely to remain, or become, the speaker's cognitively and socially dominant language. Similarly, language immersion pupils, whose degree of future continued participation in the language movement is uncertain and subject to great variation between individuals (Sallabank 2013:219; Wilson 2009:24-25), are by no means guaranteed to have a decisive role in developing the linguistic norms of the future, which remain contested. In these respects the Manx situation is perhaps a more typical example of what to expect when a second language is maintained over the long term in small networks of enthusiasts and activists who are mostly adult learners, rather than the process of rapid and complete language shift from Yiddish (and other languages) to Revived Hebrew, followed by 'normal' L1 language transmission in subsequent generations (and assimilation to this L1 norm of subsequent generations of immigrants), which characterizes the Israeli experience.

\section{Manx: Historical background}

Manx is the autochthonous heritage language of the Isle of Man, a self-governing British crown dependency in the Irish Sea with a population of c. 83,000. It is closely related to Irish and Scottish Gaelic, although mutual intelligibility is low without prior familiarization or study (Ó hIfearnáin 2015a:114-15). In its revived variety (or varieties), Manx is spoken by several hundred people, ${ }^{1}$ predominantly as a second language acquired either in adolescence or adulthood, or since 2001 through immersion primary school education (Clague 2009). Some cases of 
family intergenerational transmission have been reported (Sallabank 2013:146; Ó hIfearnáin 2015b:47), but remain rare. Manx is today a network language used predominantly at formal and informal language-focused events, in certain friendship and acquaintance circles, a handful of households and workplaces, and in online digital environments. The language in its historical vernacular form was already moribund by the mid-nineteenth century (Broderick 1999; Miller 2007). Ned Maddrell (b. 1878), generally reported to be the last native speaker (or semispeaker; Lewin 2017a:191-93), died in 1974, and language revitalization efforts in the mid-twentieth century centred on documenting and emulating the Manx of Maddrell and a number of other elderly speakers, as well as the study of written texts, most notably the eighteenth-century Bible translation. A significant degree of continuity between the traditional and revived varieties is thus generally claimed by those involved in the language movement (Sallabank 2012:101; Ó hIfearnáin 2015b:48).

There is now a considerable literature on Manx language policy and planning, predominantly from historical, sociological, linguistic anthropological, and ethnographic perspectives (e.g. Broderick 1999:173-87, 2013b; Gawne 2000, 2002, 2003; Ó hIfearnáin 2007, 2015a,b; Wilson 2008, 2009, 2011; Ager 2009; Clague 2009; George \& Broderick 2009; Mannette 2012; Sallabank 2012, 2013; Lewin 2015, 2017b; McCooey-Heap 2015; Wilson, Johnson, \& Sallabank 2015; Ó Murchadha \& Ó hIfearnáin 2018), covering areas such as the institutional developments in immersion education, adult learning, the linguistic landscape, and the experiences, aspirations, and ideologies of those engaged in the language movement.

However, there has been relatively little published research on the formal linguistic features of Revived Manx varieties, or on the processes of corpus planning, pedagogy, and second language acquisition by which the language has been and is being 'revived', including the degree of continuity or disjuncture between the natively spoken and revived varieties. More consideration is also needed of the ways in which linguistic features interact with factors external to the linguistic code, especially the ideological stances of speakers. A small number of studies have examined specific linguistic features of the revived variety of Manx: for example, Clague (2004-2005) on discourse markers, Kewley Draskau (2005) on verbal inflection and periphrasis, Broderick (2013a) and Lewin (2015) predominantly on lexis, and McNulty (2019) on certain morphosyntactic features. The dissertation (Lewin 2016a) on which the present article is based was the first work to attempt a general overview or classification of the linguistic features of the revived language.

In this article, we shall consider a variety of phonological, morphosyntactic, and lexical features whereby Revived Manx usage may diverge from the traditional variety. These can often be shown to reflect various factors including:

- substratal influence from the societally dominant language, and L1 of most Revived Manx speakers, English;

- the impact of prominent ideological stances within the revival movement throughout its history; 
- internal factors specific to the linguistic structure and orthographic tradition of Manx, both independently and with regard to their similarity to or divergence from English structures and orthography;

- inaccuracies or omissions (from the perspective of the traditional language) in key pedagogical and reference works.

The coining of new terminology is not discussed in detail in the present article, as this has been covered to a certain extent elsewhere (Broderick 2013a; Lewin 2015, 2017b). We also consider briefly countervailing tendencies towards maintenance of traditional features.

\section{Sources and representativeness}

Examples of the features discussed are taken primarily from a corpus of written sources dating from the mid-twentieth century onwards, as well as videos and audio recordings of interviews with Revived Manx speakers which have been published as learning resources on YouTube and Culture Vannin's learnmanx.com website; a full list of sources is given in Appendix B. More extensive analysis of this dataset is provided in Lewin (2016a). I have also drawn on my own experience as a member of the Revived Manx community over the past two decades. The speakers of Revived Manx from whom the examples are derived all learnt Manx in adolescence or adulthood, and may vary in proficiency, but all can express themselves reasonably fluently and confidently and would generally be regarded within the community as 'speakers' rather than 'learners' (cf. Ó hIfearnáin 2015b:57-58).

It is difficult to say how representative the speakers are, and how widespread the features highlighted are. The revival community is small, and speakers' pathways in terms of acquiring and using the language, as well as their current language ideologies and practices, are markedly varied, and at present there is probably not a sufficient density of speakers, especially of L1 speakers, to facilitate systematic levelling or koineization comparable to the processes of new dialect formation described by Trudgill (1986). It has been noted that networks of L2 speakers of minority languages in non-traditional environments display a high degree of variation and heterogeneity in their linguistic practices, such that is difficult to make any straightforward generalizations about features that are characteristic of the variety (e.g. Moal, Ó Murchadha, \& Walsh 2018; Nance 2018). The following description of the situation of new speakers of Scottish Gaelic in Glasgow is likely to be typical of situations of this kind:

\footnotetext{
a growing community of adult new speakers plays an important role in what can be considered as the Glasgow Gaelic-speaking community. Analysis of their phonetic behaviour... suggests that, so far, there is little evidence of a consistent group variety developing. Instead, there is substantial individual variation which can be linked to explicit and implicit aims of what it means to be a new Gaelic speaker. (Nance 2018:224-25)
}

In a similar vein, Ó hIfearnáin (2015a:116, 2015b:57) describes how the lack of a clearly defined target variety for Manx results in a situation where the usage of the 
most fluent speakers constitutes a 'moving target'. Notwithstanding the difficulty of generalizing about the characteristics of Revived Manx, I would judge from my own experience that all of the features described here are reasonably frequently encountered in contemporary Manx speech or writing, or are at least illustrative of wider trends. Quantitative research into specific linguistic features has the potential to shed further light on the prevalence of different variants, and on the relationship between subgroups of speakers (cf. McNulty 2019). However, a broad-based introduction of the kind offered here may be considered a helpful initial orientation.

\section{LA NGUAGE IDEOLOGYAND L INGU IST IC F O R M S}

Before proceeding to examine the linguistic features, it is useful to sketch some aspects of the ideological stances towards linguistic forms prevalent within the Revived Manx community, drawing on previous discussion in the literature. There have been differences of opinion as to the aims of the Manx language movement from the beginning. Early figures in the late nineteenth century took a largely 'preservationist' view (Stowell 2005:400, 406): they aimed to preserve Manx literature as an antiquarian pursuit, but saw little hope of practical revival of the language as an everyday vernacular, and in some cases were actively opposed to such an objective. Towards the end of the 1890s, pan-Celtic enthusiasm reached the island and a more radical approach was taken to teaching the language, including to children, but initial hopes in some quarters for a dramatic revival were soon frustrated as public interest waned and the realities of already advanced language shift were recognized (Broderick 1999:174-75; Maddrell 2001:89-96).

In more recent times the 'preservationist' view, strictly speaking, has hardly been in evidence, with most of those involved in the language movement being committed to practical revernacularization in some form. There have, however, always been different opinions as to the appropriate degree of adherence to traditional models deriving from the native speakers and writers of the past, and the degree to which revival should entail the 'correction' of (real or perceived) English influence on Traditional Manx, or accept such features as part of the fabric of the language. I have described a spectrum between 'purist' and 'authenticist' (or 'reverse purist') stances (Lewin 2015, 2017b), which is further discussed by Ó hIfearnáin (2015a):

Lewin (2015) describes the most active Manx speakers as falling into two broad currents with regard to the nature and standard of the language. He calls them 'purists' and 'authenticists'. Those who take a purist stance tend to perceive Manx as having decayed in vocabulary and grammar, particularly under the influence of English. Taking a pan-Gaelic stance, they prefer to use native words and expressions or Gaelic-derived equivalents rather than ones that display English influence, even if they are well attested in the literature and recordings of the native speakers. ... Lewin (2015) also highlights examples of current Manx usage which are based on Irish and Scottish models but which were not attested in Manx and a purist tendency to reject English-derived forms that might be in use in Ireland or Scotland in favour of newly-coined Manx neologisms.

In Lewin's view (2015) the 'authenticist' stance is a form of reverse purism, minimising aspects of neology creation and pan-Gaelicism in speech and writing, instead striving to use a form of 
language that draws as much as possible on native classical Manx. This stance may be gaining ground as electronic access to the Bible and other classical Manx texts has facilitated access to those forms of the language. (Ó hIfearnáin 2015a:112-13)

Stowell (2005:406) refers to a similar dichotomy with reference to 'preservationist' and 'revivalist' wings in the membership of Coonceil ny Gaelgey (the official Manx translation and terminology committee), although these labels are perhaps not entirely accurate, as discussed above. Recently, the two currents have come to be recognized and labelled by some within the language community as 'revivalist' $(\approx$ 'purist', Stowell's 'revivalist') and 'revisionist' $(\approx$ 'authenticist', 'preservationist'), since the latter tendency is perceived as seeking to revise established norms of the revived language in light of corpus evidence from traditional sources.

However, these ideological differences have not led to significant open conflicts or the emergence of explicit factions or named linguistic varieties (Lewin 2015:30; Ó hIfearnáin 2015a:113; Ó Murchadha \& Ó hIfearnáin 2018:465), unlike in the case of Cornish, for example (Davies-Deacon 2017). Indeed, many Manx revivalists are aware of the conflicts within the Cornish movement, and tend to regard them as a cautionary tale (Gawne 2000:141; Ó hIfearnáin 2015a:116).

What I have labelled 'purism' has long been a predominant ideological strand within the Manx movement, as reflected notably by Fargher's influential English-Manx dictionary (Fargher 1979) in his lexicographical choices and in the preface of the work (Lewin 2017b), and can be traced to early figures in the revival such as J. J. Kneen in the early twentieth century (Maddrell 2001:96-97). Lexical purism in Revived Manx is also discussed by Broderick (2013a:8-26, 2013b:142-61) and Ó hIfearnáin (2015a:107-09). Indeed, the dominance of this ideology is asserted without caveat by Gawne (2000:142), who was a language development officer at the time of writing:

\footnotetext{
Our lack of a native-speaking community has some advantages and many other disadvantages. The advantages include a general improvement on the grammar which was used by the native speakers and a re-instatement of Gaelic words where English words had been substituted in later spoken Manx, the most famous example being corran buigh ('yellow crescent') instead of banana. ... We also strongly believe in using Gaelic neologisms rather than English loan-words. In creating new words we endeavour to generate words from within the Manx language, however, Manxifying Irish and Scottish Gaelic loan words comes a close second. (Gawne 2000:142)
}

Nonetheless, an 'authenticist' current has long existed within the language movement, notably represented in the second half of the twentieth century by the Celtic scholar and long-term member of Coonceil ny Gaelgey, Robert L. Thomson. 'Authenticist' stances are characterized by a concern not to depart too far from the traditional language, and are accepting of well-established Englishderived lexis or constructions, rather than 'native' replacements or pan-Gaelic borrowings, especially if the latter are felt to depart from the 'character of the language' (Thomson's words, quoted in Lewin 2017b:103). As noted above, such 'authenticist' perspectives appear to have had a new lease of life in recent years, as online publication of traditional texts in digital format as well as audio 
recordings of native speakers, now available on YouTube (Manx National Heritage 2017), have made such sources more accessible, and the divergences of the revived language from native usage more apparent. The long-established dominant 'purist' stances appear to remain widespread in the broader Revived Manx community, although there are now a number of prominent younger 'authenticist' voices in Coonceil ny Gaelgey and other positions of influence.

Details of the range of ideological positions both in the Manx community and elsewhere are undoubtedly considerably more complex than the simple bipolar spectrum described in the present brief discussion. Nonetheless, in broad terms, dichotomies of the kind described here have been widely observed in situations of language endangerment and revitalization including such cases as Breton (Jones 1995; Hornsby \& Quentel 2013), Cornish (Davies-Deacon 2017), Occitan (Costa 2015), Corsican (Jaffe 1999), Galician (Alvarez 1990), Basque (Urla 2015), Irish (Ní Ghearáin 2011; O'Rourke \& Walsh 2020), and Hawaiian (Wong 1999; NeSmith 2003).

In the case of Breton, for example, most L2 speakers broadly embrace mainstream 'Neo-Breton' stances and linguistic practices which have been widely described as being characterized by supradialectal standardization, lexical purism (rejection of French borrowings, even if long-established in the traditional dialects), borrowings from other Celtic languages, alongside pervasive French syntactic and phonological substrate features of which speakers may be largely unaware (Jones 1995; Le Pipec 2013; Hornsby \& Quentel 2013). Some revivalist speakers, however, espouse what Hornsby \& Quentel (2013:78-82) label as a 'native authenticist' ideology: they valorize native dialectal varieties, attempting to acquire and use these as far as possible, and reject the conscious lexical purism of mainstream Neo-Breton. This is broadly comparable to the Manx situation, with the main difference that the possibility of direct interaction with native speakers and their linguistic varieties is no longer part of the picture in the case of Manx.

It has been suggested that puristic stances tend to emerge as the default ideology of many language revitalization movements because such assumptions are congruent with the dominant discourses concerning purity, monolingualism, and homogeneity in established standard (European or Western) national languages (Jaffe 1999:146-59, 185-90, 271-85), which are internalized by speakers of the minority language. In Jaffe's (1999:23) terms, a 'resistance of reversal', which resists the outcomes of language domination but not its underlying 'structures of value', arises more readily within revitalization movements - and seems more intuitive to most speakers, immersed as they are in the ideological frames of the dominant culture - than 'radical models of resistance' (Jaffe 1999:29) which challenge dominant assumptions around monolingualism, linguistic standardization, and identification of language with nation. Alternative stances are more likely to arise at a subsequent stage among those who begin to perceive and problematize the growing gap between traditional and revitalization varieties, and among those aware of and influenced by the descriptivist assumptions of most contemporary linguistics. $^{2}$ They seem particularly likely to emerge among those engaged in 
professional or amateur scholarship of the traditional variety of the language in question, that is, individuals with significant metalinguistic awareness of the different varieties, and personal investment in knowledge of the historical vernacular norms. Of course, ideological stances which originate in an intellectual subgroup (a 'counterelite', in Hornsby \& Quentel's (2013:78) terms), without necessarily having buy-in from the wider language community, are not unproblematic in terms of power dynamics and potential accusations of elitism, not to mention practical effectiveness and reach, even if, as in the case of the so-called 'sociolinguistic' ideology of polynomie in the case of Corsican, they are explicitly intended to be egalitarian and inclusive (Jaffe 2008; Sallabank 2010).

As discussed by Ó hIfearnáin (2007:167), an overarching priority for most Revived Manx speakers - regardless of their particular views on linguistic details - has been pragmatism, and a concern not to let questions of linguistic form get in the way of the expansion and elaboration of the language movement. This kind of pragmatism, however, tends to be most closely allied with the dominant purist ideology - not necessarily because there is a direct or inherent link between the two, but because individuals with relatively little personal interest or investment in formal linguistic questions and metalinguistic debates are likely to gravitate to whatever the majority view on these matters happens to be.

\section{S U B S T R A T A L FEAT U R E S}

As would be expected from the literature on language contact and second language acquisition, as well as language revitalization and revival more specifically, substratal impacts from English, the first language of most Revived Manx speakers, are widespread.

\section{Loss of syllable-final $\mathrm{r}$, intrusive $\mathrm{r}$}

The phenomena of loss of syllable-final / $r$ in (1) and intrusive / $r$ / in (2) are very frequent (the relevant syllables are highlighted in bold). These well-known developments are typical of many varieties of English, including that of the Isle of Man (Jackson 1955:118; Hamer 2007:173), but are not otherwise usual in Gaelic varieties.

(1) a. $\mathrm{RM}^{3}$ (Taggloo $)^{4}$

[va mə ' $J a n, \varepsilon:$ t $\int i t$ st $\left.\int a x\right]$

va my shenn-ayr cheet stiagh

be:PST my old-father come:vN in

'my grandfather would come in'

b. RM (Taggloo)

[p3:t lə mu.ə]

Purt le Moirrey

'Port St Mary' 
(2) a. RM (Taggloo)

[sai ${ }^{\text {}} \mathrm{n}$ dau g.ı: nax vel monə t.ı: $\mathbf{x}$ eməs]

shegin dou gra nagh vel monney traa $/ \mathbf{r} / \mathbf{a y m}$ 's

COP:PRs:need to:me say:vN COMP:NEG be:PRS much time at:me:EMPH

'I must say that I don't have much time'

b. RM (Taggloo)

[va mi beə. $\mathbf{r}$ uns du:lif]

va mee beaghey /r/ ayns Doolish

be:PST I live:vN in Douglas

'I was living in Douglas'

c. RM (Taggloo)

[fодə $\mathbf{x}$ еðə henə]

foddey $/ \mathbf{r} /$ er-dy-henney

long ago

'long ago'

Both of these phenomena were found to some extent in the Traditional Manx of the last speakers recorded in the mid-twentieth century (see (3) and (5) below), and rhotic deletion is already reported in the nineteenth century (Rhŷs 1894:148), although the details are somewhat different. In Traditional Manx the loss of $/ r$ / did not necessarily alter the preceding vowel as in (3), whereas in Revived Manx the vowel often corresponds to English pronunciation as in (4) where earlier /ur/, / عr/, / rr/ have all become /3:/, and traditional /uə/ ( </urr/) (retained in conservative varieties of both Received Pronunciation and Manx English) is increasingly smoothed to a long monophthong. ${ }^{5}$

(3) a. TM (HLSM II:112)

[ko] [kor] [kur]

cur

'put, give, send'

b. TM (HLSM II:127)

[du:t], [dut]

dooyrt

'said'

(4) a. RM (heard by author)

[k3:]

cur

'put, give, send'

b. RM (heard by author)

[d3:t], [do:t]

dooyrt

'said' 
(5) TM: intrusive $r$ in late Traditional Manx (HLSM II:267):

[ha 'rau mi 'ru: e:vil 'lai ç rəðə]

cha row mee rieau abyl lhaih eh $/ \mathbf{r} /$ edyr

NEG be:PST I ever able read:vN it at.all

'I was never able to read it [Manx] at all'

\section{Interchange of emphatic and non-emphatic pronouns}

Some Revived Manx speakers appear not to control fully the pragmatic difference between plain and morphologically marked emphatic pronouns found in Traditional Manx. ${ }^{6}$ Such emphatic pronouns are characteristic of the Gaelic languages and are generally used in contexts where English would employ heavy phonetic stress to indicate an explicit or implied contrast between two or more actors. In (6) the non-emphatic prepositional pronoun $o c$ 'by them' (Ir. $a c u$ ) is phonetically heavily stressed and is pragmatically contrastive with the speaker's reference to himself, but lacks the expected emphatic suffix (ocsyn, Ir. acusan), whereas it appears as expected in aym's 'at me, my' (Ir. agamsa).

(6) RM (Taggloo)

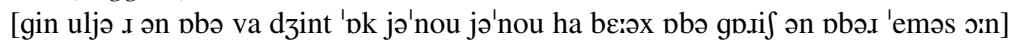

gyn ooilley $/ \mathrm{r} /$ yn obbyrva jeant oc you know you know

without all the:SG work be:PST done at:them

cha beagh obbyr gollrish yn obbyr aym-'s ayn

NEG be:COND work like the:SG work at:me-EMPH in:it

'without all the work that was done by them you know you know there would not be work like $m y$ work'

In (7), we find the plain form used in an emphatic context in a video from a series of Manx lessons, perhaps because the emphatic forms have not yet been taught at this point in the course. In the exchange, A uses the plain pronoun $e h$ 'he' with heavy stress where the emphatic form eshyn would be expected.

(7) RM (Saase Jeeragh 2)

A: [vel u ski: dzu:]

Vel oo skee jiu?

be:PRS:INT you:sG tired today

'Are you tired today?'

B: ['ta mi ski: dzu:]

Ta mee skee jiu.

be:PRS I tired today

'I am tired today'

$[\ldots]$ 


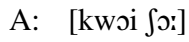

Quoi shoh?

who this

'Who is this?'

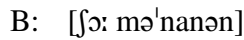

Shoh Manannan.

this Manannan

'This is Manannan'

A: [vel 'ei ski: dzu:]

Vel eh skee jiu?

be:PRS:INT he tired today

'Is he tired today?'

B: [ha nel e: ski:]

Cha nel eh skee.

NEG be:PRs he tired

'He is not tired'

The unfamiliarity of the Gaelic plain-emphatic distinction to L1 English speakers is likely to make it difficult to acquire in any case, and the pedagogical choice in (7) may increase the probability of fossilization of the non-traditional usage.

Some Revived Manx speakers seem to have reanalysed the emphatic pronouns as something akin to the disjunctive pronouns of French (moi, toi, etc.), or the generalized disjunctive use of the historical object pronouns in English (e.g. 'It's me'), that is, stressed pronominal forms used in syntactic environments other than verbal subject or direct object. For example, the emphatic pronouns are frequently used in circumstantial clauses introduced by subordinating as 'and' (G. agus, is) (see e.g. Ó Siadhail 1991:284-87 and Vennemann 2012:189-93 for descriptions of this clause type in Irish), irrespective of the pragmatic or semantic nuances conveyed by the distinction between plain and emphatic pronouns in Traditional Manx. In (8) the emphatic form ish 'she' (Ir. ise), as opposed to plain ee (Ir. i), would in Traditional Manx imply contrast with another actor, but no one else is mentioned: the passage concerns the effects of the fact that the character has to look after the baby, not about whether it is she or someone else who is looking after it; nor is there a pragmatic contrast between her and the baby.

(8) RM (Ecstasy:28)

Cha beagh ee abyl jannoo lieh cho wheesh as veagh urree jannoo NEG be:COND she able do.vN half as as.much as be:COND on:her do:vN

as ish jeeaghyn mysh y lhiannoo beg and she:EMPH look:vN about the:sG baby little

'She would not be able to do half as much as she would have to do when she was looking after the little baby' 
Compare the Traditional Manx examples (9a) where there is a plain pronoun and no contrastive sense, and (9b) where there is an emphatic pronoun and an element of contrast between emphatic shiuish 'you' and the child.

(9) a. TM (Bible, Numbers 5:30)

Ny tra ta 'n spyrryd dy eadaghey dy ghoaill eh, as eh or when be:PRS the:SG spirit of jealousy PRON take:VN him and he geadaghey myshe ven, as dy choyrt lesh y ven roish be:jealous:VN about his wife and PRON bring:VN with:him the woman before

y Chiarn, nee 'n saggyrt cooilleeney urree ooilley'n leigh shoh the Lord do:FUT the:SG priest execute:vN on:her all the:SG law this

'Or when the spirit of jealousy cometh upon him, and he be jealous over his wife, and shall set the woman before the Lord, and the priest shall execute upon her all this law'

b. TM (Sharmaneyn:160)

Ta shiu er vakin paachey as mooarane taitnys echey be:PRS you:PL PFV see:vN child and much pleasure at:him

er e ghaieaghyn, as goail feer olk rish scarrey roo: oor ny on his toy:PL and take:VN very bad to part:vN with:them hour 3sG:M

lurg, foddee, $\mathrm{t}$ ' eh bwoailt lesh chingys, as shiuish streeu after perhaps be:PRs he strike:PTCP with illness and you:PL:EMPH strive:VN dy vrynneragh rish lesh ny eer gaieaghyn ve tammylt roish to coax:VN with:him with the:PL very toy:PL be:PST:he while before shen as wheesh dy haitnys echey ayndoo; agh ooilley ayns fardail: that and so.much of pleasure at:him in:them but all in vain

ta 'n eer shilley jeu cur corree er be:PRS the:sG very sight of:them put:vN anger on:him

'You have seen a child extremely fond of his playthings, and most impatient to part with them: an hour after, perhaps, he is taken ill, and you strive to divert him by the things he was just before so very fond of; but all in vain: the very sight of them offends him'

FEATURES REFLECTING DOMINANT

L A N G U A E IDE OL O G Y

Certain features may be interpreted as reflective of the dominant 'purist', panGaelic language ideology discussed above. It is known that removal of English influence was a priority for revivalists such as the lexicographer Douglas Fargher 
(Lewin 2017b), as the following quotation from the preface of his English-Manx dictionary shows:

It always appalled me to hear the last few native speakers interspersing accounts of their travels in Manx with the anglicised renderings of Gaelic names. This unnecessary dependence upon English cannot be tolerated if the Manx language of the future is to survive in its own right, and has, therefore, been discouraged here. (Fargher 1979:vi)

\section{Avoidance of long-standing loanwords}

In Traditional Manx, including in the Bible translation, the English loanword back is generally used for the adverb sense of returning to a prior location as in (10a), where $a(i) r$ ais would be usual in other Gaelic varieties. The cognate native adverbial er-ash exists in Traditional Manx, but has developed specialized senses of 'flourishing, blooming' or 'coming to light after being lost' as in (10b) (Broderick 2013a:18-20; Lewin 2015:25).

a. TM (Bible, Luke 8:40)

As haink eh gy-kione, tra va Yeesey er jeet back, and come:PST it to head when be:PST Jesus PFV come:vN back

dy ghow yn pobble lane boggey jeh

COMP take.PST the.SG people much joy of:him

'And it came to pass, that, when Jesus was returned, the people gladly received him'

b. TM (Bible, Isaiah 17:11)

ayns y voghrey ver oo er dty rass dy heet er-ash in the:SG morning put:FUT you:SG on your seed to come forth 'in the morning shalt thou make thy seed to flourish'

For many speakers of Revived Manx however, er-ash is used for 'back' as in (11) and the Traditional Manx sense of er-ash is unknown. Thus a potentially useful semantic distinction is lost.

(11) RM (Taggloo)

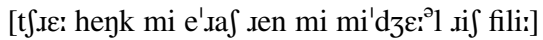

tra haink mee er ash ren mee meeiteil rish Phillie

when come:PST I back do:PST I meet:vN with Phillie

'when I came back I met Phillie'

\section{Hyper-Gaelicisms}

Another type of purism concerns the coining of new constructions which apparently are felt to be closer to the spirit of Gaelic idiom (and less similar to English constructions), even if the exact structure in question, or context of usage, does 
not exist either in Traditional Manx or other Gaelic varieties. These we term hyperGaelicisms.

For example, in Traditional Manx 'I hope' was generally expressed by the regular verb treishteil (also 'trust') as in (12).

(12) TM (Ned Beg:121)

ta mee treishteil nagh jean lheid cheet orrym arragh ayns my vea be:Prs I hope:vN COMP:NEG do:FUT such come:vN on:me anymore in my life 'I hope that I don't experience the like anymore in my lifetime'

However, many speakers of Revived Manx are more familiar with, and regularly use, a copula and preposition construction s'treisht lhiam (lit. 'is hope with me') as in (13), which is unattested in the traditional language. Fargher's (1979:393-94) dictionary has only jerkal (also 'expect', sometimes 'hope' in TM) and ta treisht aym lit. 'I have hope', suggesting that the construction has become established in the revived language more recently.

(13) RM (Taggloo)

[stı\&:S ljəm sə tıع: .

S' treisht lhiam 'sy traa ry-heet neeym goll

COP:PRS hope with:me in:the:sG time to come:VN do:FuT:1SG go:VN

dys Nherin ny s'menkey

to Ireland COMPAR COP:PRS often:COMPAR

'I hope in the future I will go to Ireland more often'

An early occurrence, but without the prepositional pronoun, is found in Thomson's preface to his edition of Goodwin's First lessons in Manx, shown in (14).

(14) RM (Thomson 1966)

Ta mee er hirrey er- y- fa shen ny shenn varranyn be:PRS I PFV seek:VN on the:SG reason that the:PL old error:PL

y ghaartlian ass dy bollagh, gyn marranyn noa y chur lhiam VN weed:VN out ADV complete without error:PL new vN bring:VN with:me

stiagh - s' treisht ec y chooid sloo dy vel shen in cop:PRs hope at the:SG part COP:PRS:least COMP be:PRS that

er jeet lhiam

PFV come:vN with:me

'I have sought therefore to weed out the old errors completely, without introducing new errors - it is hoped at least that I have succeeded in that'

No construction of the type is $X$ le (copula + noun + experiencer headed by preposition le 'with') is in common use for 'to hope' in any Gaelic variety (cf. 
Ir. ta súil agam 'I have hope', lit. 'I have an eye', or tá mé ag súil 'I am hoping'; ScG. tha mi an dòchas 'I am in hope'). The Revived Manx innovation is part of a wider tendency to expand the use of copula structures, which are apparently felt to be more distinctively Gaelic and less English (Lewin 2016a:64-73).

\section{Hyper-archaisms}

Especially in written Revived Manx, there may be attempts to restore older features. For example, Kewley Draskau (2005) has noted a tendency towards increased use of inflected verb tenses (e.g. vrie mee 'I asked') as opposed to the semantically interchangeable 'do'-periphrasis (ren mee briaght lit. 'I did ask'), contrary to the diachronic trend in the traditional language.

Forms may be restored to those considered historically 'correct', even when these may in fact have been obsolete or ungrammatical in attested periods of the traditional language, as shown by the following case. The progressive proclitic *ag (originally a preposition 'at') has been elided entirely in Manx apart from the survival of the consonant $/ \mathrm{g} /$ as a prefix on vowel-initial verbal nouns, as in geaishtagh 'listening', Ir. ag éisteacht, lit. 'at listening'. By the eighteenth century it had become usual to prefix this $g$ - to vowel-initial verbal nouns in other constructions besides the progressive as in (15).
a. $\quad$ TM (Bible, Jeremiah 44:5)
cha ren ad geaishtagh
NEG do:PST they listen:vN
'they hearkened not'
(earlier: cha ren ad eaishtagh, lit. 'they did not do a listening')

b. TM (Bible, Joshua 22:28)

dy vod mayd gansoor
COMP can:PRS 1PL answer:vN
'that we may say again [answer]'
(earlier: ....ansoor)

I have argued that the $g$ - prefix had been reanalysed as a general marker of non-finite verbs in Classical Manx, to the extent that omission of $g$ - (with a few lexical exceptions) in the non-progressive constructions was probably no longer grammatical (Lewin 2016b:191-99). In Revived Manx, however, bare forms of the verbal noun without $g$ - are sometimes found, as in (16).

a. RM (Thomson 1969)

Cha nodmayd obbal dy vel marranyn 'sy lioar shoh

NEG can:PRS:1PL deny:vN COMP be:PRS error:PL in:the:SG book this

'We cannot deny that there are errors in this book'

(TM: gobbal) 
b. RM (Skeealaght:3)

cha jeanym imraa e ennym

neg do:FUT:1SG mention:vN his name

'I will not mention his name'

(TM: gimraa)

It is likely that this represents conscious restoration of the historical, perceived more 'logical' construction, especially in view of the fact these are written sources and Thomson (see (16a)) was a professional scholar of the Gaelic languages.

\section{MA INTENANCE OF TRADITIONAL FEATURES}

Although the focus in this article is primarily on ways in which Revived Manx usage diverges from the historical language, it is worth noting that there are also instances of retention of traditional elements, especially of pronunciation, even where these are not indicated in writing. These can be considered part of the oral tradition of the revival, having been acquired by the mid-twentieth-century revivalists who interacted with the final traditional speakers (cf. Ó Murchadha \& Ó hIfearnáin 2018:464).

\section{Preocclusion}

Preocclusion is a feature of Traditional Manx involving the insertion of an often weakly articulated homorganic stop before final liquids in stressed syllables (Rhŷs 1894:142-44; Jackson 1955:113-15; Broderick 1984-1986:vol. 3, 28-34; Lewin 2020:308-36), not found in other Gaelic varieties. Preocclusion has never been written in the standard orthography, but is quite widely encountered in Revived Manx (see (17)). It seems to be especially common in certain words and therefore may be considered to have been lexicalized by revival speakers. The articulation may also be somewhat different from Traditional Manx, being more distinctly articulated and more likely to be realized syllabically (cf. English syllabic liquids in words such as paddle). Usage is variable; in (17a) the same speaker has the same item with and without preocclusion.

a. RM (Taggloo; same speaker)

[kiən], [e. ə xidn]

keayn, er y cheayn (ScG. cuan, air a' chuan)

'sea, on the sea'

b. $\mathrm{RM}$

$\left[\mathrm{g}^{\mathrm{j}} \mathrm{l}^{\mathrm{j}} \mathrm{o}^{\mathrm{d}} \mathrm{n}\right]$ glione 'glen', G. gleann (Taggloo)

[ $\left.\mathrm{e}^{\mathrm{d}} \mathrm{n}\right]$ shen 'that', G. sin (Taggloo)

[hi: 'n] hene 'self', ScG. fhìn (Caine)

[sledn] slane 'fully', G. slán (Caine) 
Features such as preocclusion in Revived Manx are likely to represent retention or restoration of particularly salient or iconic linguistic features (i.e. distinctively 'Manx' as opposed both to English and other Gaelic varieties), which are seen as a link to the historical language and thus a marker of linguistic authenticity (cf. Irvine \& Gal 2000; Ó hIfearnáin 2015b:56-57; McNulty 2019:17, 55-56). They can fulfil this iconic function at the same time as other features of the traditional language are disregarded or altered, whether knowingly or unknowingly.

\section{Dialect}

Traditional Manx is recognized as having had a primary dialect distinction between north and south (Rhŷs 1894:160-61; Broderick 1984-1986:vol. 3, 160-66), although the differences are relatively slight. Speakers from both regions survived into the mid-twentieth century and were recorded and interacted with the revivalists. Revived Manx speakers today tend to have features historically associated with both southern and northern Manx, although metalinguistic awareness of the traditional dialects seems to be low for the majority of speakers. In some cases, a pronunciation reflecting one dialect has become widespread, even though the spelling better represents the other dialect. It is possible that these represent further cases of iconization of traditional, orthographically non-transparent pronunciations.

For example, a diphthongal pronunciation of the word kione 'head' (G. ceann) and the compound mychione (preposition 'about, concerning') is frequent, reflecting the northern form, although the spelling better represents the southern monophthongal realization as in (18).

(18) RM (Taggloo)

diphthongal (i.e. 'northern') [mə'kjaun] [mə'çaun]

monophthongal (i.e. 'southern') [mə'kjən] [mə'ço:n] mychione 'about'

Similarly, the historically northern pronunciation of shenn 'old' (G. sean) with /a/ is considerably more common in Revived Manx than southern and orthographic /e/ (cf. Broderick 1984-1986:vol. 2, 398).

A few speakers make a conscious effort to adopt one dialect or the other. This includes both the handful remaining who had personal contact with particular traditional speakers, as well as newer speakers making use of the recorded and transcribed material. For example, the revival speaker interviewed in (19) uses the northern diphthongal form [ei] for oie 'night' (G. oidhche), rather than the southern form [i:] which is usual in revival speech.

RM (Crellin)

Interviewer: [ki.əd te gic: son i: vai]
C'red t'ou (?)
gra son 'oie vie'?
what be:PRs:you:sG say:vN for night good
'What do you (?) say for oie vie (goodnight)?' 
Interviewee: [ei vai e.. ə tuii]

'[ei vai] oie vie' er y twoaie

night good on the:sG north

'[ei vai] in the north'

IN TERNAL LANGUAGE-SPECIFIC FACTOR S

\section{Internal analogy and overgeneralization}

Some divergences from Traditional Manx usage cannot be attributed directly to English influence per se, but rather to internal analogy or overgeneralization. That is, speakers innovate features or patterns that might appear to be logically possible - or even required - in the structure of the traditional language, but which are in fact unattested, or were expressed in other ways, and appear to have been ungrammatical or at least dispreferred in the historical variety. For example, in Manx the concept 'only' can be expressed with a negative verb and agh 'but' in (20), as in Irish (Ó Siadhail 1991:218).

(20) TM (Bible, Acts 2:15)

Son cha vel ad shoh er- meshtey, myr ta shiuish

for NEG be:PRS they this on drunkenness as be:PRS you:PL:EMPH

dy heiltyn, fakin nagh vel eh agh yn trass oor jeh'n laa PRON think:VN See:VN COMP:NEG be:PRS it but the:SG third hour of the:SG day

'For these are not drunken, as ye suppose, seeing it is but the third hour of the day'

In Revived Manx the negative copula cha nee is sometimes found in clefting structures followed by agh 'but, only' in the sense 'it is only' as in (21).

(21) RM (Droghad:2)

cha nee agh eiyrtys y taghyrt vees ry akin roish shen

NEG COP:PRS but effect the:SG event:GEN be:FUT:REL to see:vN before that

'it is only the effect of the event which will be visible before that'

As far as is known, this configuration is unattested in Traditional Manx, ${ }^{7}$ even though clefting is very frequent otherwise. That these two focusing constructions appear to be syntactically incompatible in the traditional language is perhaps related to the fact that clefting locates the focused item to the left edge of the clause, whereas the agh construction favours shifting of the focused constituent rightwards (cf. McCloskey 1980:64-66). 


\section{Spelling pronunciations}

The Manx orthography, which is based largely on English conventions but with significant innovations to represent distinctive Manx sounds, is notorious both among scholars and revivalists for its complexity and inconsistency (Ó hIfearnáin 2007; Lewin 2020:59), although no serious replacement has ever been proposed. It is unsurprising that spelling pronunciations are frequent, some of which have become well established.

For example, the digraph $<$ ay $>$ may represent a variety of vowel sounds as in $(22){ }^{8}$

(22) TM

$\begin{array}{llll}\text { /e:/ } & \text { cray 'clay' } & \text { (G. cré) } \\ \text { /e:/ } & \text { ayr 'father' } & \text { (G. athair) } \\ \text { /o/, /u/ } & \text { ayns 'in' } & \text { (ScG. anns) } \\ \text { /o:/ /u:/ } & \text { ayn 'in him, it' } & \text { (G. ann) } \\ \text { /e/ } & \text { aym 'at me' } & \text { (G. agam) } \\ \text { /a:/ } & \text { tayrn 'pull' } & \text { (G. tarraing) }\end{array}$

The adjective maynrey 'happy' is expected to have /e:/ (G. méanar, méanra $<$ Early Irish mo-génar) and is attested thus in Traditional Manx speech as in (23), but frequently has [a:] in revival speech as in (24).

(23) TM (HLSM II:293)

[mendra] [mẽ:ndrəs] [me:ndərəs]

maynrey, maynrys

'happy, happiness'

(24) RM (Lessoonyn:16)

[ma:n.ə(s)]

maynrys

'happiness'

The revival pronunciation may be traced to Kneen's English-Manx pronouncing dictionary (1938:38) as in (25).

(25) RM (Kneen 1938:38)

(mahnris, mahnra)

maynrys, maynrey

'happiness, happy'

The Manx orthography usually roughly follows the Modern English values of the vowel symbols (i.e. the outcomes of the Great Vowel Shift), but sometimes the latinate values are found, as also in English (cf. combine and machine). This leads to confusion, for example, in the following pair in (26) and (27), which I have heard confused in RM speech. 
(26) TM (cf. Rhŷs 1894:46-47)

/maian/

Mian (G. Maitheán)

'Matthew'

(27) TM (HLSM II:298)

$/$ mion/ [mi:n]

mian (G. mian)

'desire'

\section{Incomplete or erroneous information in reference works}

Certain forms attested in Revived Manx can be shown to derive from erroneous or incomplete descriptions of the traditional language in the tradition of the revival, as documented and transmitted in widely used reference works.

In Manx there is a class of complex prepositions formed from an original simple preposition together with a noun, and with pronominal forms involving possessives (analogous to English 'for my sake', 'in his stead'). Sometimes there is elision of the original simple preposition. An example in Traditional Manx is quail 'towards, meeting' (G. i gcomhdháil 'in the meeting (of)'), which as expected has pronominal forms based on the possessives, given in (28).

a. TM (Bible, 2 Samuel 19:15)

As haink Judah gys Gilgal, dy gholl quail y ree and come:PST Judah to Gilgal to go:vN in:meeting the:sG king 'And Judah came to Gilgal, to go to meet the king'

b. TM (Bible, Matthew 28:9)

$\begin{array}{llll}\text { haink } & \text { Yeesey } & \text { nyn } & \text { guail } \\ \text { come:PST } & \text { Jesus } & \text { in:their } & \text { meeting } \\ \text { 'Jesus met them' } & & \end{array}$

The preposition quail followed by a noun phrase complement in (28a) is well-attested in Traditional Manx sources. However, a misconception about this has appeared in various reference works in (29), where it is stated or implied that the possessive is required even when there is a non-pronominal complement. According to Fargher (1979:488), there is agreement with the gender and number of the complement as in ny quail ben 'to meet a woman' (29c), cf $n y$ quail 'towards her'. Such constructions are not found in with any other complex preposition in Manx or in other Gaelic varieties.

(29) a. 'I met a man.' Haink mee ny whaiyl dooinney.

(Kneen 1931:188)

b. The following lacks a simple preposition, 'towards, to meet':

Sg. 1 my whaiyl, 2 dty whaiyl, $3 \mathrm{~m}$. ny whaiyl, 3f. ny quaiyl; Pl. nyn guaiyl. 
c. 'I met a man', Haink mee ny whail dooinney. 'I met a woman', Haink mee ny quail ben.

d. As well as the verb meeiteil, 'meet' is usually translated by goll/çheet ny whaiyl, with the appropriate form of the possessive:

Haink mee ny whaiyl dooinney 'I met a man'

Haink ee my whaiyl 'She met me'

Higym dty whaiyl 'I shall meet you'

(Kewley Draskau 2008:184)

Accordingly, the redundant possessive is often used in Revived Manx in (30) (albeit in these examples without number agreement), as well as another innovating variant where it is compounded with the preposition rish 'to, with' as in (30c), perhaps reflecting the synonymous construction meeiteil rish 'to meet (with)', and a mixed form with both possessive and rish as in (30d). The Traditional Manx construction with simple quail + nominal complement is also found in revival usage as in (30e).

(30) a. RM (Skeealaght:23)

va caa da Thom cheet ny whaiyl ymmodee sleih be:PST opportunity to Tom come:vN in:his meeting many people gagh oie each night

'Tom had an opportunity to meet many people each night'

b. RM (Skeealaght:26)

haink eh ny whaiyl ny fir elley come:PST he in:his meeting the:PL ones other 'he met the others'

c. RM (Caine)

[heyk mi xwe:l rif on gau]

haink mee quail rish yn Gaaue come:PST I in:meeting with the:SG Gaaue 'I met the Gaaue'"

d. RM (Skeealaght:59)

higmayd nyn guaiyl ry cheilley come:FUT:1PL in:our meeting with one.another 'we will meet one another'

e. $\mathrm{RM}$ (Crellin)

[heyk mi kweil iljəm ə Jadlax]

haink mee quail Illiam y Radlagh 
come.PST I in:meeting William Radcliffe

'I met William Radcliffe'

It is clear that the variety of forms in (30) reflects the existence of conflicting models: the usage of the traditional language (and the analogy of other complex prepositions) on the one hand, and the prescriptions of several notable Revived Manx reference works in (29) on the other. The persistence, from the 1930s to the 2000s, of the belief that the preposition quail lacks a non-conjugated form, and that the conjugated forms can be combined with a governed noun phrase, is striking. No other structure in the language behaves like this, so the innovation runs contrary to the rationalizing, analogical tendency discussed above. It is clear testimony to the abiding influence of successions of reference works and the usage of influential individuals in the revival which have been accorded authority within the community.

\section{O N C L U S I O N}

The present article has presented a typology of characteristic innovating features of contemporary Manx, a postvernacular language in the process of revival within a relatively small network of second language speakers and learners. We have traced a complex set of internal and external factors which are likely to be present in any language revival scenario, as well as particular traits of the linguistic and orthographic relationship between Manx and English, and specific historical developments and ideological trends in the course of the revival.

The kind of 'hybridization' noted by Zuckermann (2009) in the case of Israeli Hebrew is clearly apparent in Revived Manx; however, there is also an ongoing dynamic of malleability whereby features of the target variety remain fluid and variable in the absence of a definitive 'founder generation' and subsequent nativization as a dominant L1. Although we have seen that there is clearly a specific oral and written tradition within the Manx revival which has a significant impact, for example, through perpetuating idiosyncrasies from earlier textbooks, or certain traditional phonological features, nevertheless each succeeding generation of revival speakers remains in some sense part of an extended 'founder generation', able consciously to reshape the language and introduce or restore features in a non-linear fashion.

This can be regarded as a symptom of the relative weakness of the language revival and its failure to achieve robust intergenerational sociolinguistic vitality; however, the current fluidity of the language's norms can also be viewed more positively as empowering present and future cohorts of Manx speakers. The future development of the language is subject to their conscious reflexive choices in a way not true of 'natural' L1s-including, now, Hebrew (cf. Blanc 1957:399). In the latter, language change is largely an incremental and unconscious phenomenon, and deliberate manipulation of the linguistic code plays only a small part; 
whereas in a small network of L2 revival speakers, influential individuals, groups, or publications can potentially have a disproportionate impact in modifying linguistic norms and practices. This has been true over past decades in the Manx revival community, and is likely to remain the case.

The features of Manx which have been noted in this article are thus not necessarily set in stone to the degree they might be had Revived Manx gained a significant cohort of native speakers in the earlier stages of the revival, as occurred in the case of Hebrew. In the present circumstances, it is unclear whether and to what extent the ideological stances discussed above will continue to be as influential in the Revived Manx community as they have been to date, and how far future norms will adhere to or diverge from models derived from the traditional language. These questions are to a significant degree in the hands of Manx speakers themselves as they participate in an ongoing project of creative renewal and reimagining the language they have chosen to (re)claim and make their own. As discussed above, this is likely to be true of many other language revitalization contexts in which adult L2 learners are numerically dominant, and where traditional native speakers are absent, or contact with them is limited.

\section{A P P E N D IX A : A B B R E V I A T I O N S}

General ABBREVIATIONS:

$\begin{array}{ll}\text { G. } & \text { Gaelic (Irish or Scottish Gaelic) } \\ \text { Ir. } & \text { Irish } \\ \text { lit. } & \text { literally } \\ \text { RM } & \text { Revived Manx } \\ \text { ScG. } & \text { Scottish Gaelic } \\ \text { TM } & \text { Traditional Manx }\end{array}$

GLossing ABbreviations:

$\begin{array}{ll}\text { ADV } & \text { adverbial } \\ \text { COMP } & \text { complementizer } \\ \text { COMPAR } & \text { comparative/superlative } \\ \text { COND } & \text { conditional } \\ \text { COP } & \text { copula } \\ \text { EMPH } & \text { emphatic } \\ \text { FUT } & \text { future } \\ \text { GEN } & \text { genitive } \\ \text { INT } & \text { interrogative } \\ \text { M } & \text { masculine } \\ \text { NEG } & \text { negative } \\ \text { PFV } & \text { perfective }\end{array}$




$\begin{array}{ll}\text { PL } & \text { plural } \\ \text { PRON } & \text { pronominal particle } \\ \text { PRS } & \text { present } \\ \text { PST } & \text { past } \\ \text { PTCP } & \text { participle } \\ \text { REL } & \text { relative (verb form) } \\ \text { SG } & \text { singular } \\ \text { VN } & \text { verbal noun/verbal noun particle } \\ 1,2,3 & \text { first, second, third person }\end{array}$

A P P E N D IX B : P R I M A R Y S O U R C E S

Revived Manx sources:

SPOKEN MATERIAL:

Caine Culture Vannin. Bernard and Joan Caine Interviews.

Online: http://www.learnmanx.com/cms/video_collection_79769.html; accessed January 18, 2021.

Crellin Culture Vannin. Juan Crellin [interviews].

Online: http://www.learnmanx.com/cms/video_collection_31498.html; accessed January 18, 2021.

Saase Jeeragh Culture Vannin. Saase Jeeragh video files.

Online: http://www.learnmanx.com/cms/video_collection_74051.html; accessed January 18, 2021. Reference is to the number of the lesson.

Taggloo Culture Vannin (2014). Taggloo: Conversational Manx.

Online: https://www.youtube.com/watch?v=lPygOMM8Fk4\&list= PLY5y-gRhKs8gmP0sMWYlmp25dl1b0TWeu; accessed January 18, 2021. YouTube playlist.

WRITTEN MATERIAL

Droghad

Lewin, Christopher (2010). Droghad ny Seihill. Douglas: Yn Cheshaght Ghailckagh.

Ecstasy

Ó Laighléis, Ré, \& Robert W. K. Teare (trans.) (2008). Ecstasy as Skeealyn Elley. St Judes: Yn Cheshaght Ghailckagh.

Lessoonyn Culture Vannin. Lessoonyn Meanagh.

Online: http://www.learnmanx.com/cms/inter_lesson_index.html; accessed January 18, 2021. References are to the number of the lesson.

Skeealaght $\quad$ y Crellin, Lewis; Juan y Crellin; Colin y Jerree; \& Shorys y Creayrie (1976). Skeealaght. Douglas: Yn Cheshaght Ghailckagh. 
Thomson 1966 Thomson, Robert L. (1966). Gys y lhaihder [To the reader]. In Edmund Goodwin \& Robert L. Thomson, First lessons in Manx. Lessoonyn ayns Chengey ny Mayrey Ellan Vannin. 3rd edn. Douglas: Yn Cheshaght Ghailckagh.

Thomson 1969 Thomson, Robert L. (1969). Gys y lhaihder [To the reader]. In Archibald Cregeen, A dictionary of the Manks language. 3rd edn. Menston: Scolar Press.

Traditional ManX sources:

Bible Bible in Manx, 1819 Bible Society edition.

Online: https://www.bible.com/versions/1702-bib1819-yn-viblecasherick-1819; accessed January 18, 2021.

HLSM All examples of Traditional Manx speech are from George Broderick (1984-1986), A handbook of Late Spoken Manx, 3 vols. Tübingen: Niemeyer.

Ned Beg Broderick, George (1981). Manx stories and reminiscences of Ned Beg Hom Ruy. Zeitschrift für celtische Philologie 38:113-78.

Sharmaneyn Wilson, Thomase (1783). Sharmaneyn liorish Thomase Wilson [Sermons by Thomas Wilson]. Bath: Cruttwell.

\section{N O T E S}

*The data discussed in this article were originally presented in a master's thesis completed at Aberystwyth University in 2016, and also in a paper delivered at the Celtic Linguistics Conference, Maynooth University, in September 2018. I am grateful to my thesis supervisors William Mahon and Simon Rodway, and my examiners Peadar Ó Muircheartaigh and Tadhg Ó hIfearnáin, as well as to the editors of Language in Society, two anonymous reviewers, and a number of friends and colleagues, who provided helpful comments on earlier drafts.

${ }^{1}$ The number of residents able to speak Manx was reported as 1,662 in the 2011 census (Isle of Man Government Treasury 2012:27), although the number of highly fluent individuals is likely considerably lower (Ó hIfearnáin 2015b:54).

${ }^{2}$ Revivalists may embrace a folk version of the tenet of descriptive linguistics that language change is natural, inevitable, and value-neutral, applying it to the dichotomy between traditional and revived varieties. This 'permits a naturalised opposition between old and new that resolves the potential ideological tension between the monolingual native speaker and the second language learner by reducing both categories to naturally occurring variation' (Costa 2015:142). This is a significant discourse in the Manx language movement, serving to emphasize continuity, despite change, from the traditional language, and downplaying or rejecting the concept of language death (Sallabank 2013:54; Lewin 2016a:9-12, 23-28).

${ }^{3}$ In the examples throughout the article the following labels are used: $\mathrm{TM}=$ Traditional Manx, RM = Revived Manx. Glossing generally follows the Leipzig conventions (see https://www.eva.mpg. de/lingua/resources/glossing-rules.php/), with abbreviations given in Appendix A.

${ }^{4}$ Abbreviated titles of the primary sources for the examples are given in parentheses and full references are listed in Appendix B. References are to page numbers unless otherwise stated in the appendix.

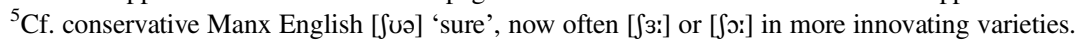




\section{CHRISTOPHER LEWIN}

${ }^{6}$ See Mac Eoin (1986) and Cotter (1994) for descriptions of usage of these constructions in Modern Irish.

${ }^{7}$ No cases were found in a search of currently digitized TM texts including the Manx Bible. A search for analogous constructions in Irish (ní ach ... etc.) and Scottish Gaelic (chan ann ach... etc.) in online text corpora (New Corpus for Ireland; Historical Irish Corpus 1600-1926; Corpas na Gàidhlig) produced a small number of instances. However, use of the construction appears to be marginal and generally alternate constructions are preferred, as in Traditional Manx. According to James McCloskey (p.c.), UC Santa Cruz, at least some subtypes of the ní ach construction are rejected by L1 Gaeltacht Irish speakers.

${ }^{8}$ This ambiguity principally reflects a conflict between an older northern Middle English and Scots convention of using $<y>$ (or $<\mathrm{i}>$ ) to mark vowel length ( $>$ Manx $/ \mathrm{a}:$ ) (Lewin 2020:67), and the Modern English use of $<$ ay $>$ to represent /er/ ( $>$ Manx /e:/ and $/ \varepsilon: /)$.

${ }^{9}$ 'The Blacksmith', i.e. John Kneen (c. 1852-1958), one of the last native speakers of Manx.

\section{R E F E RENCES}

Ager, Simon (2009). A study of language death and revival with a particular focus on Manx Gaelic. Bangor: Bangor University dissertation.

Alvarez, Celso (1990). The institutionalization of Galician: Linguistic practices, power, and ideology in public discourse. Berkeley: University of California dissertation.

Blanc, Haim (1957). Hebrew in Israel: Trends and problems. Middle East Journal 11:397-409.

Broderick, George (1984-1986). A handbook of Late Spoken Manx. 3 vols. Tübingen: Niemeyer. (1999). Language death in the Isle of Man. Tübingen: Niemeyer.

(2013a). Neologisms in revived Manx Gaelic. Studia Celtica Fennica 10:7-29.

(2013b). The revival of Manx Gaelic in the Isle of Man. Scottish Gaelic Studies 29:132-71.

Clague, Marie (2004-2005). Cross-linguistic discourse markers in Manx Gaelic and English. Proceedings of the Harvard Celtic Colloquium 24/25:195-205.

(2009). Manx language revitalization and immersion education. e-Keltoi Journal of Interdisciplinary Celtic Studies 2:165-98.

Corpas na Gàidhlig, Digital Archive of Scottish Gaelic (DASG). University of Glasgow. Online: http:// dasg.ac.uk/corpus/.

Costa, James (2015). New speakers, new language: On being a legitimate speaker of a minority language in Provence. International Journal of the Sociology of Language 231:127-45.

Cotter, Colleen (1994). Focus in Irish and English: Contrast and contact. In Susanne Gahl, Andy Dolbey, \& Christopher Johnson (eds.), Proceedings of the twentieth annual meeting of the Berkeley Linguistics Society: General session dedicated to the contributions of Charles J. Fillmore, 134-44. Berkeley, CA: Berkeley Linguistics Society.

Davies-Deacon, Merryn (2017). Names, varieties and ideologies in Revived Cornish. Studia Celtica Posnaniensia 2:79-93.

Fargher, Douglas C. (1979). Fargher's English-Manx dictionary. Douglas: Shearwater Press.

Gawne, Philip (2000). Aithne na nGael: Life after death. In Gordon McCoy \& Maolcholaim Scott (eds.), Aithne na nGael: Gaelic identities, 129-43. Belfast: Ultach Trust.

(2002). Securing the future of Manx Gaelic. In Peter Davey \& David Finlayson (eds.), Mannin revisited: Twelve essays on Manx culture and environment, 173-83. Edinburgh: Scottish Society for Northern Studies.

(2003). Y Ghaelg as ynsagh ayns Mannin. In Maolcholaim Scott \& Róise Ní Bhaoill (eds.), Gaelic-medium education provision: Northern Ireland, the Republic of Ireland, Scotland and the Isle of Man, 133-44. Belfast: Cló Ollscoil na Banríona.

George, Ken, \& George Broderick (2009). The revived languages: Cornish and Manx. In Martin J. Ball \& Nicole Müller (eds.), The Celtic languages, 753-69. London: Routledge. 


\section{CONTINUITY AND HYBRIDITY IN LANGUAGE REVIVAL}

Goodwin, Edmund, \& Robert L. Thomson (1966). First lessons in Manx. 3rd edn. Douglas: Yn Cheshaght Ghailckagh.

Hamer, Andrew (2007). English on the Isle of Man. In David Britain (ed.), Language in the British Isles, 171-75. Cambridge: Cambridge University Press.

Hinton, Leanne, \& Jocelyn Ahlers (1999). The issue of 'authenticity' in California language restoration. Anthropology \& Education Quarterly 30:56-67.

Historical Irish Corpus (1600-1926). Royal Irish Academy. Online: http://corpas.ria.ie/.

Hornsby, Michael, \& Gilles Quentel (2013). Contested varieties and competing authenticities: Neologisms in revitalized Breton. International Journal of the Sociology of Language 223:71-86.

Irvine, Judith T., \& Susan Gal (2000). Language ideology and linguistic differentiation. In Paul V. Kroskrity (ed.), Regimes of language: Ideologies, politics, and identities, 35-83. Santa Fe, NM: School of American Research Press.

Isle of Man Government Treasury (2012). Isle of Man census report 2011. Online: https://www.gov. $\mathrm{im} /$ media/207882/census2011reportfinalresized_1_.pdf; accessed January 18, 2021.

Jackson, Kenneth (1955). Contributions to the study of Manx phonology. Edinburgh: Nelson.

Jaffe, Alexandra (1999). Ideologies in action: Language politics on Corsica. Berlin: Mouton de Gruyter.

(2008). Language ecologies and the meaning of diversity: Corsican bilingual education and the concept of 'polynomie'. In Angela Creese, Peter Martin, \& Nancy H. Hornberger (eds.), Encyclopedia of language and education, vol. 9: Ecology of language, 225-36. Berlin: Springer.

Jones, Mari C. (1995). At what price language maintenance? Standardization in modern Breton. French Studies 49:428-36.

Kewley Draskau, Jennifer (2005). Language death and resurrection in the Isle of Man: The continuity of Manx Gaelic exemplified by the use of inflected verb tenses. Proceedings of the Harvard Celtic Colloquium 25:229-46.

- (2008). Practical Manx. Liverpool: Liverpool University Press.

Kneen, J. J. (1931). A grammar of the Manx language. London: Oxford University Press. (1938). English-Manx pronouncing dictionary. Douglas: Mona's Herald.

Le Pipec, Erwan (2013). Les trois ruptures sociolinguistiques du breton. International Journal of the Sociology of Language 223:103-16.

Lewin, Christopher (2015). Classical Manx, Revived Manx and English: Competing standards. In P. Sture Ureland (ed.), Minority languages in Europe and beyond: Results and prospects, 23-31. Berlin: Logos.

(2016a). The revivability of Manx Gaelic: A linguistic description and discussion of Revived Manx. Aberystwyth: Aberystwyth University dissertation.

(2016b). The syntax of the verbal noun in Manx Gaelic. Journal of Celtic Linguistics 17:147-239.

- (2017a). 'Manx hardly deserved to live': Perspectives on language contact and language shift. Zeitschrift für celtische Philologie 64:141-205.

- (2017b). Scholarship and language revival: Language ideologies in corpus development for Revived Manx. Studia Celtica Posnaniensia 2:97-118.

- (2020). Aspects of the historical phonology of Manx. Edinburgh: University of Edinburgh dissertation. Online: https://era.ed.ac.uk/handle/1842/37271; accessed January 19, 2021.

Mac Eoin, Gearóid (1986). Treise sa Ghaeilge agus sa Bhéarla. In Seosamh Watson (ed.), Féilscríbhinn Thomáis de Bhaldraithe, 27-35. Baile Átha Cliath: Coiste Fhéilscríbhinn Thomáis de Bhaldraithe.

Maddrell, Breesha Catherine (2001). Contextualising a vocabulary of the Anglo-Manx dialect: Developing Manx identities. Liverpool: University of Liverpool dissertation.

Mannette, Antonia (2012). Language learning in pubs, tea rooms and other non-formal settings. Edmonton: University of Alberta dissertation. 


\section{CHRISTOPHER LEWIN}

Manx National Heritage (2017). Skeealyn Vannin: Manx language and dialect recordings. [YouTube playlist.] Online: https://www.youtube.com/playlist?list=PLxvEbuf5XvSubAhwdDxX9xBf14pf AxB5d; accessed January 18, 2021.

McCooey-Heap, Katherine (2015). 'There's a boat in the morning!': An investigation into linguistic identity construction and maintenance on the Isle of Man. Ormskirk: Edge Hill University dissertation.

McCloskey, James (1980). Is there raising in Modern Irish? Ériu 31:59-99.

McNulty, Erin (2019). An investigation into the morphosyntax of Revitalised Manx Gaelic. Cambridge: University of Cambridge dissertation.

Miller, Stephen (2007). 'Here the Manx language lingers, and may linger some time longer': Manx and English in Cregneash in 1901. Zeitschrift für celtische Philologie 55:108-21.

Moal, Stefan; Noel P. Ó Murchadha; \& John Walsh (2018). New speakers and language in the media: Audience design in Breton and Irish broadcast media. In Cassie Smith-Christmas, Noel P. Ó Murchadha, Michael Hornsby, \& Máiréad Moriarty (eds.), New speakers of minority languages: Linguistic ideologies and practices, 189-212. London: Palgrave Macmillan.

Nahir, Moshe (1998). Micro language planning and the revival of Hebrew: A schematic framework. Language in Society 27:335-57.

Nance, Claire (2018). Linguistic innovation among Glasgow Gaelic new speakers. In Cassie Smith-Christmas, Noel P. Ó Murchadha, Michael Hornsby, \& Máiréad Moriarty (eds.), New speakers of minority languages: Linguistic ideologies and practices, 213-30. London: Palgrave Macmillan.

NeSmith, Keao (2003). Tūtū's Hawaiian and the emergence of a Neo-Hawaiian language. 'Óiwi Journal: A Native Hawaiian Journal 3:67-76.

New Corpus for Ireland. Foras na Gaeilge. Online: http://corpas.focloir.ie/.

Ní Ghearáin, Helena (2011). The problematic relationship between institutionalised Irish terminology development and the Gaeltacht speech community: Dynamics of acceptance and estrangement. Language Policy 10:305-23.

Ó hIfearnáin, Tadhg (2007). Manx orthography and language ideology in the Gaelic continuum. In Jean-Michel Eloy \& Tadhg Ó hIfearnáin (eds.), Langues proches-langues collatérales/Near languages-collateral languages, 159-70. Paris: Harmattan.

- (2015a). Back to the future: Standard and language standards in contemporary Manx Gaelic. Sociolinguistica: Internationales Jahrbuch für europäische Soziolinguistik 29:99-120.

- (2015b). Sociolinguistic vitality of Manx after extreme language shift: Authenticity without traditional native speakers. International Journal of the Sociology of Language 231:45-62.

Ó Murchadha, Noel, \& Tadhg Ó hIfearnáin (2018). Converging and diverging stances on target revival varieties in collateral languages: The ideologies of linguistic variation in Irish and Manx Gaelic. Journal of Multilingual and Multicultural Development 39:458-69.

O'Rourke, Bernadette, \& John Walsh (2020). New speakers of Irish in the global context: New revival? New York: Routledge.

Ó Siadhail, Mícheál (1991). Modern Irish grammatical structure and dialectal variation. Cambridge: Cambridge University Press.

Rhŷs, John (1894). The outlines of the phonology of Manx Gaelic. Douglas: Manx Society.

Sallabank, Julia (2010). Standardisation, prescription and polynomie: Can Guernsey follow the Corsican model? Current issues in language planning 11:311-30.

(2012). Diversity and language policy for endangered languages. In Bernard Spolsky (eds.), The Cambridge handbook of language policy, 100-23. Cambridge: Cambridge University Press.

(2013). Attitudes to endangered languages: Identities and policies. Cambridge: Cambridge University Press.

Stowell, Brian (2005). The case of Manx Gaelic. In Diarmuid Ó Néill (ed.), Rebuilding the Celtic languages: Reversing language shift in the Celtic countries, 383-416. Talybont: Y Lolfa.

Trudgill, Peter (1986). Dialects in contact. Oxford: Blackwell. 


\title{
CONTINUITY AND HYBRIDITY IN LANGUAGE REVIVAL
}

Urla, Jacqueline (2015). Reclaiming Basque: Language, nation, and cultural activism. Reno: University of Nevada Press.

Vennemann, Theo (2012). Semitic $\rightarrow$ Celtic $\rightarrow$ English: The transitivity of language contact. In Patrizia Noel Aziz Hanna (ed.), Germania Semitica, 179-218. Berlin: De Gruyter Mouton.

Wilson, Gary N. (2008). The revitalisation of the Manx language and culture in an era of global change. In Irené Novacek (ed.), Refereed papers from the third International Small Island Cultures Conference, 74-81. Charlottetown: Institute of Island Studies, University of Prince Edward Island.

(2009). 'But the language has got children now': Language revitalisation and education planning in the Isle of Man. Shima: The International Journal of Research into Island Cultures 3(2):15-31.

(2011). Social change and language revitalization in the Isle of Man: A post-materialist perspective. Language Documentation and Description 9:58-74.

; Henry Johnson; \& Julia Sallabank (2015). 'I'm not dead yet': A comparative study of indigenous language revitalization in the Isle of Man, Jersey and Guernsey. Current Issues in Language Planning 16:259-78.

Wong, Laiana (1999). Authenticity and the revitalization of Hawaiian. Anthropology \& Education Quarterly 30:94-115.

Zuckermann, Ghil'ad (2009). Hybridity versus revivability: Multiple causation, forms and patterns. Journal of Language Contact 2(2):40-67.

(2020). Revivalistics: From the genesis of Israeli to language reclamation in Australia and beyond. Oxford: Oxford University Press.

, \& Michael Walsh (2011). Stop, revive, survive: Lessons from the Hebrew revival applicable to the reclamation, maintenance and empowerment of Aboriginal languages and culture. Australian Journal of Linguistics 31:111-27.

(Received 4 June 2020; revision received 23 January 2021; accepted 4 February 2021; final revision received 22 February 2021)

\author{
Address for correspondence: \\ Christopher Lewin \\ Welsh and Celtic Studies \\ Aberystwyth University \\ Parry-Williams Building \\ Aberystwyth SY23 3AJ, Wales \\ ch175@aber.ac.uk
}

